\title{
Phytotoxic Effects of Plant Essential Oils: A Systematic Review and Structure-Activity Relationship Based on Chemometric Analyses
}

\author{
Ahmed M. Abd-ElGawad 1,2,*iD, Abd El-Nasser G. El Gendy ${ }^{3} \mathbb{D}$, Abdulaziz M. Assaeed ${ }^{1} \mathbb{D}$, Saud L. Al-Rowaily ${ }^{1}$, \\ Abdullah S. Alharthi ${ }^{1}$, Tarik A. Mohamed ${ }^{4}$, Mahmoud I. Nassar ${ }^{5}$, Yaser H. Dewir ${ }^{1,6}{ }^{D}$ \\ and Abdelsamed I. Elshamy ${ }^{5,7}$ iD
}

check for updates

Citation: Abd-ElGawad, A.M.; El Gendy, A.E.-N.G.; Assaeed, A.M.; Al-Rowaily, S.L.; Alharthi, A.S.; Mohamed, T.A.; Nassar, M.I.; Dewir, Y.H.; Elshamy, A.I. Phytotoxic Effects of Plant Essential Oils: A Systematic Review and Structure-Activity Relationship Based on Chemometric Analyses. Plants 2021, 10, 36. https://dx.doi.org/ 10.3390/plants10010036

Received: 16 November 2020 Accepted: 23 December 2020 Published: 25 December 2020

Publisher's Note: MDPI stays neutral with regard to jurisdictional claims in published maps and institutional affiliations.

Copyright: () 2020 by the authors. Licensee MDPI, Basel, Switzerland. This article is an open access article distributed under the terms and conditions of the Creative Commons Attribution (CC BY) license (https: / / creativecommons.org/ licenses/by/4.0/).
1 Plant Production Department, College of Food and Agriculture Sciences, King Saud University, P.O. Box 2460, Riyadh 11451, Saudi Arabia; assaeed@ksu.edu.sa (A.M.A.); srowaily@ksu.edu.sa (S.L.A.-R.); 437105762@ksu.edu.sa (A.S.A.); ydewir@ksu.edu.sa (Y.H.D.)

2 Department of Botany, Faculty of Science, Mansoura University, Mansoura 35516, Egypt

3 Medicinal and Aromatic Plants Research Department, National Research Centre, Cairo 11865, Egypt; aggundy_5@yahoo.com

4 Chemistry of Medicinal Plants Department, National Research Centre, 33 El-Bohouth St., Dokki, Giza 12622, Egypt; ta.mourad@nrc.sci.eg

5 Chemistry of Natural Compounds Department, National Research Centre, 33 El Bohouth St., Dokki, Giza 12622, Egypt; mnassar_eg@yahoo.com (M.I.N.); ai.el-shamy@nrc.sci.eg (A.I.E.)

6 Department of Horticulture, Faculty of Agriculture, Kafrelsheikh University, Kafr El-Sheikh 33516, Egypt

7 Faculty of Pharmaceutical Sciences, Tokushima Bunri University, Yamashiro-Cho, Tokushima 770-8514, Japan

* Correspondence: aibrahim2@ksu.edu.sa; Tel.: +20-1003438980

\begin{abstract}
Herbicides are natural or synthetic chemicals used to control unwanted plants (weeds). To avoid the harmful effects of synthetic herbicides, considerable effort has been devoted to finding alternative products derived from natural sources. Essential oils (EOs) from aromatic plants are auspicious source of bioherbicides. This review discusses phytotoxic EOs and their chemical compositions as reported from 1972 to 2020. Using chemometric analysis, we attempt to build a structure-activity relationship between phytotoxicity and EO chemical composition. Data analysis reveals that oxygenated terpenes, and mono- and sesquiterpenes, in particular, play principal roles in the phytotoxicity of EOs. Pinene, 1,8 cineole, linalool, and carvacrol are the most effective monoterpenes, with significant phytotoxicity evident in the EOs of many plants. Caryophyllene and its derivatives, including germacrene, spathulenol, and hexahydrofarnesyl acetone, are the most effective sesquiterpenes. EOs rich in iridoids (non-terpene compounds) also exhibit allelopathic activity. Further studies are recommended to evaluate the phytotoxic activity of these compounds in pure forms, determine their activity in the field, evaluate their safety, and assess their modes of action.
\end{abstract}

Keywords: allelopathy; bioherbicides; volatile oils; terpenes; aromatic plants

\section{Introduction}

Humans have been cultivating plants for nearly 10,000 years ago. Today, any plant growing where it is not wanted is defined as a weed. Weeds represent an important constraint to agricultural production [1]. Weeds represent approximately $0.1 \%$ of the world's flora and they evolve with agricultural practices. Weeds can cause declines in crop yields via competition for resources such as light, water, space, and nutrients, and by producing chemical weapons known as allelopathic compounds [2]. Weed management is achieved using several techniques to limit infestation and minimize competition. These techniques evolved to mitigate crop yield losses, but weed control is typically used only after a problem has been identified. 
Scientists and researchers address weed control through physical, chemical, and biological methods. Controlling weeds in an environmentally friendly way is often considered a challenge. Natural resources offer new approaches to producing eco-friendly, and safe bioherbicides that are effective against nuisance weeds. Plants produce the essential oils (EOs) in their various organs as a complex mixture of secondary metabolites such as mono-, sesquit-, and di-terpenoids in addition to hydrocarbons $[3,4]$. In plants, EOs were biosynthesized via different isoprenoid pathways such as methylerythritol phosphate (MEP) pathway and mevalonic acid (MVA) pathway [5]. The EOs have been described as potent biological agents such as phytotoxic [6-9], antimicrobial [10], anti-inflammatory, antipyretic [11], antiulcer [12], and hepatoprotective [13]. The bioactivities potential of EOs are directly correlated with the quality and quantity of their chemical constituents [6]. Many studies have been performed using the extracted EOs from various plants as phytotoxic chemicals (allelochemicals), where the phytotoxicity is usually correlated to the whole EO profile that contained a mixture of compounds. However, the activity of the EO could be ascribed to a specific compound(s) in the EO. Therefore, in the present review, we try to elucidate a framework of the most frequent and major allelochemicals that were identified in the EOs with a substantial phytotoxic activity using chemometric tools. Additionally, the activities of the authentic identified major compounds are discussed.

\section{Materials and Methods}

This review focuses on reports of EOs from plants that exhibit phytotoxic activity published between 1972 and early 2020, using Google, Sci-finder, Google Scholar, PubMed, Elsevier, and Springer databases. Based on the major compounds (those constituting $>5 \%$ of the total mass of the EO), the plants were categorized into three groups; mono-, sesqui-, and non-terpenoid-rich compounds. Firstly, the database of EOs rich in monoterpenes derived from plants comprised 46 species belonging to 12 botanical families, including Lamiaceae (18 species), Myrtaceae (nine species), Asteraceae (eight species), Anacardiaceae (three species), and Cannabaceae, Euphorbiaceae, Monimiaceae, Pinaceae, Poaceae, Verbenaceae, Winteraceae, and Apiaceae (a single species each). Additionally, the EOs of these plants were tested against 49 plant species.

Secondly, the plant EOs rich in sesquiterpenes from 25 plant species belonging to eight botanical families were studied. The most represented botanical families were Lamiaceae and Asteraceae (nine plant species each), while Anacardiaceae, Boraginaceae, Fabaceae, Myrtaceae, Simaroubaceae, Verbenaceae, and Chenopodiaceae were represented by a single species. All the EOs of these plants were investigated against 13 plant species. Thirdly, six plant EOs rich in non-terpenoid compounds were identified belonging to Lamiaceae (three species), Apiaceae (two), and Cucurbitaceae (one), were tested against 17 plants.

To assess the correlation of EOs phytotoxic activity and structural compounds, a data matrix of each group was performed as a spreadsheet in MS-EXCEL. A matrix of 42 major monoterpene compounds from 45 plant species was assembled, while a matrix of 26 sesquiterpene compounds, identified in the EOs of 22 plant species was prepared. These matrices were subjected to PCA using XLSTAT software version 14 (Addinsoft, New York, NY, USA).

\section{Phytotoxic EOs Derived from Plants Rich in Monoterpenes}

The EOs from different plant species with monoterpenes as the main compounds that exhibited significant phytotoxic activity against various target plant species are presented in Table 1. Zhang, et al. [14] concluded that monoterpene-rich EOs derived from Eucalyptus salubris, E. dundasii, E. spathulata, and E. brockwayii strongly inhibited germination and seedling growth in Solanum elaeagnifolium relative to commercial Eucalyptus oil and 1,8-cineole. Moreover, the EO of E. salubris was found to be the most powerful inhibitor of germination and roots and shoot growth, while E. spathulata exhibited the lowest effect [14]. 
Table 1. Monoterpene-rich EOs derived from various reported plants with significant allelopathic activity.

\begin{tabular}{|c|c|c|c|}
\hline Plant Name & Main Monoterpenoid Compounds & Phytotoxic against & Reference \\
\hline Euphorbia heterophylla & 1,8-cineole, camphor, & Cenchrus echinatus * & [6] \\
\hline Symphyotrichum squamatum & $\beta$-pinene & Bidens pilosa * & [15] \\
\hline Salvia sclarea & $\begin{array}{l}\text { 1-linalool, linalyl acetate, } \alpha \text {-terpineol, } \\
\text { and geraniol }\end{array}$ & $\begin{array}{l}\text { Lactuca sativa, Lepidium sativum, } \\
\text { and Portulaca oleracea* }\end{array}$ & [16] \\
\hline Schinus terebinthifolius & $\begin{array}{l}3 \text {-carene, } \alpha \text {-pinene, limonene, } \\
\text { and } \beta \text {-pinene }\end{array}$ & Bidens pilosa * & [17] \\
\hline Cannabis sativa & $\begin{array}{l}\text { myrcene, terpinolene, } \\
\text { and }(E) \text { - } \beta \text {-ocimene }\end{array}$ & $\begin{array}{l}\text { Avena sativa, Zea mays, Brassica } \\
\text { oleracea, Avena fatua }{ }^{*} \text {, Bromus } \\
\text { secalinus }{ }^{*} \text {, Echinochloa } \\
\text { crus-galli }{ }^{*} \text {, Amaranthus retroflexus }{ }^{*}, \\
\text { Centaurea cyanus * }\end{array}$ & [18] \\
\hline Callistemon viminalis & 1,8-cineole $\alpha$-pinene, and d-limonene & $\begin{array}{l}\text { Bidens pilosa } * \text {, Cassia occidentalis *, } \\
\text { Echinochloa crus-galli }{ }^{*} \text {, and Phalaris } \\
\text { minor * }\end{array}$ & [19] \\
\hline Cymbopogon citratus & neral, geranial, and $\alpha$-pinene & Sinapis arvensis * & [20] \\
\hline Eucalyptus cladocalyx & 1.8-cineole, and $p$-cymene & & \\
\hline Origanum vulgare & carvacrol, $\gamma$-terpinene, and $p$-cymene & & \\
\hline Artemisia absinthium & $\beta$-thujone, and linalool & & \\
\hline Cymbopogon citratus & neral, geranial, and $\beta$-myrcene & Echinochloa crus-galli * & [21] \\
\hline Origanum acutidens & carvacrol, $p$-cymene, linalool acetate & $\begin{array}{l}\text { Amaranthus retroflexus *, } \\
\text { Chenopodium album *, and Rumex } \\
\text { crispus * }\end{array}$ & [22] \\
\hline $\begin{array}{l}\text { Eriocephalus } \\
\text { africanus }\end{array}$ & carvacrol, $p$-cymene, linalool acetate & $\begin{array}{l}\text { Amaranthus hybridus * and Portulaca } \\
\text { oleracea * }\end{array}$ & [23] \\
\hline Vitex agnus-castus & 1,8-cineole, sabinene, and $\alpha$-pinene & Lactuca sativa and Lepidium sativum & [24] \\
\hline Thymus daenensis & thymol, carvacrol, and $p$-cymene & $\begin{array}{l}\text { Amaranthus } \\
\text { retroflexus }{ }^{*} \text {, Avena fatua } * \text {, Datura } \\
\text { stramonium }^{*} \text {, and Lepidium sativum }\end{array}$ & [25] \\
\hline Thymus eigii & $\begin{array}{l}\text { thymol, carvacrol, } p \text {-cymene, } \\
\gamma \text {-terpinene, and borneol }\end{array}$ & $\begin{array}{l}\text { Lactuca sativa, Lepidium sativum, } \\
\text { and Portulaca oleracea * }\end{array}$ & [26] \\
\hline Thymbra spicata & carvacrol, $\gamma$-terpinene, $p$-cymene & $\begin{array}{l}\text { Triticum aestivum, Zea mays, Lactuca } \\
\text { sativa, Lepidium sativum, } \\
\text { and Portulaca oleracea * }\end{array}$ & [27] \\
\hline Nepeta flavida & linalool, 1,8-cineole, and sabinene & $\begin{array}{l}\text { Lepidium sativum, Raphanus sativus, } \\
\text { and Eruca sativa }\end{array}$ & [28] \\
\hline Heterothalamus psiadioides & $\beta$-pinene, $\delta^{3}$-carene, and limonene & Lactuca sativa and Allium cepa & {$[29,30]$} \\
\hline Salvia hierosolymitana & $\begin{array}{l}\alpha \text {-pinene, myrtenol, and sabinyl } \\
\text { acetate, }\end{array}$ & $\begin{array}{l}\text { Raphanus satious and Lepidium } \\
\text { sativum }\end{array}$ & [31] \\
\hline Artemisia scoparia & $\begin{array}{l}p \text {-cymene, } \beta \text {-myrcene, } \\
\text { and }(+) \text {-limonene }\end{array}$ & $\begin{array}{l}\text { Achyranthes aspera, } \\
\text { Cassia occidentalis *, Parthenium } \\
\text { hysterophorus *, Echinochloa crus-galli } \\
\text { *, and Ageratum conyzoides * }\end{array}$ & [32] \\
\hline Eucalyptus grandis & $\alpha$-pinene, $\gamma$-terpinene, and $p$-cymene & \multirow[t]{2}{*}{ Lactuca sativa } & \multirow[t]{2}{*}{ [33] } \\
\hline Eucalyptus citriodora & $\beta$-citronellal, geraniol, and citronellol & & \\
\hline $\begin{array}{l}\text { Plectranthus } \\
\text { amboinicus }\end{array}$ & carvacrol & Lactuca sativa and Sorghum bicolor & {$[34]$} \\
\hline
\end{tabular}


Table 1. Cont.

\begin{tabular}{|c|c|c|c|}
\hline Plant Name & Main Monoterpenoid Compounds & Phytotoxic against & Reference \\
\hline Pinus brutia & $\alpha$-pinene, and $\beta$-pinene & $\begin{array}{l}\text { Lactuca sativa, Lepidium sativum, } \\
\text { and Portulaca oleracea* }\end{array}$ & [35] \\
\hline Pinus pinea & limonene, $\alpha$-pinene, and $\beta$-pinene & $\begin{array}{l}\text { Sinapis arvensis }{ }^{*}, \text { Lolium } \\
\text { rigidum }{ }^{*} \text {, and Raphanus } \\
\text { raphanistrum * }\end{array}$ & [36] \\
\hline $\begin{array}{l}\text { Cotinus coggyria } \\
\text { Scop. }\end{array}$ & $\alpha$-pinene, limonene, and $\beta$-myrcene & $\begin{array}{l}\text { Silybum marianum *, and Portulaca } \\
\text { oleracea * }\end{array}$ & [37] \\
\hline $\begin{array}{l}\text { Zataria } \\
\text { multiflora }\end{array}$ & carvacrol, linalool and $p$-cymene & $\begin{array}{l}\text { Hordeum spontaneum }{ }^{*} \text {, Secale cereale } \\
* \text {, and Amaranthus retroflexus *, } \\
\text { and Cynodon dactylon } *\end{array}$ & [38] \\
\hline Mentha $\times$ piperita & menthol, mentone, and menthofuran & $\begin{array}{l}\text { Lycopersicon esculentum, Raphanus } \\
\text { sativus, Convolvulus arvensis *, } \\
\text { Portulaca oleracea *, and Echinochloa } \\
\text { colonum * }\end{array}$ & [39] \\
\hline Hyssopus officinalis & $\begin{array}{l}\beta \text {-pinene, iso-pinocamphone, and, } \\
\text { trans-pinocamphone }\end{array}$ & \multirow[t]{9}{*}{$\begin{array}{l}\text { Raphanus sativus, Lactuca sativa, } \\
\text { and Lepidium sativum }\end{array}$} & \multirow[t]{9}{*}{ [40] } \\
\hline Lavandula angustifolia & $\begin{array}{l}\beta \text {-pinene, iso-pinocamphone, } \\
\text { and trans-pinocamphone }\end{array}$ & & \\
\hline Majorana hortensis & $\begin{array}{l}\text { 1,8-cineole, } \beta \text {-phellandrene, } \\
\text { and } \alpha \text {-pinene }\end{array}$ & & \\
\hline Melissa officinalis & $\begin{array}{l}\text { (-)-citronellal, carvacrol, } \\
\text { and citronellol }\end{array}$ & & \\
\hline Ocimum basilicum & linalol, and borneol & & \\
\hline Origanum vulgare & $\begin{array}{l}o \text {-cymene, carvacrol, and linalyl } \\
\text { acetate }\end{array}$ & & \\
\hline Salvia officinalis & trans-thujone, camphor, and borneol & & \\
\hline Thymus vulgaris & $o$-cymene, and $\alpha$-pinene & & \\
\hline Verbena officinalis & isobornyl formate, and (E)-citral & & \\
\hline Shinus molle & $\begin{array}{l}\beta \text {-phellendrene, } \alpha \text {-phellendrene, } \\
\text { and myrcene }\end{array}$ & Triticum aestivum & [41] \\
\hline Syzygium aromaticum & eugenol, and eugenol acetate & $\begin{array}{l}\text { Mimosa pudic }{ }^{*} a \text { and Senna obtusifolia } \\
\text { M }\end{array}$ & [42] \\
\hline Peumus boldus & ascaridole, $p$-cymene and 1,8-cineole & \multirow{2}{*}{$\begin{array}{l}\text { Amaranthus hybridus * and Portulaca } \\
\text { oleracea * }^{*}\end{array}$} & \multirow[t]{2}{*}[43]{} \\
\hline Drimys winterii & $\begin{array}{l}\text { terpinen-4-ol, } \gamma \text {-terpinene, } \\
\text { and sabinene }\end{array}$ & & \\
\hline Agastache rugosa & $d$-limonene, and linalool & $\begin{array}{l}\text { Majorana hortensis *, Trifolium repens } \\
*, \text { Rudbeckia hirta, Chrysanthemum } \\
\text { zawadskii, Melissa officinalis *, } \\
\text { Taraxacum platycarpum }{ }^{*} \text {, and Tagetes } \\
\text { patula }\end{array}$ & [44] \\
\hline Eucalyptus lehmanii & 1,8 -cineole, $\alpha$-thujene, and $\alpha$-pinene & $\begin{array}{l}\text { Sinapis arvensis *, Diplotaxis harra*, } \\
\text { Trifolium campestre *, Desmazeria } \\
\text { rigida }{ }^{*} \text {, and Phalaris canariensis }{ }^{*}\end{array}$ & [45] \\
\hline Tanacetum aucheranum & $\begin{array}{l}\text { 1,8-cineole, camphor, } \\
\text { and terpinen-4-ol }\end{array}$ & \multirow{2}{*}{$\begin{array}{l}\text { Amaranthus retroflexus *, } \\
\text { Chenopodium album *, and Rumex } \\
\text { crispus * }\end{array}$} & \multirow[t]{2}{*}{ [46] } \\
\hline Tanacetum chiliophyllum & camphor, 1,8-cineole and borneol & & \\
\hline
\end{tabular}


Table 1. Cont.

\begin{tabular}{|c|c|c|c|}
\hline Plant Name & Main Monoterpenoid Compounds & Phytotoxic against & Reference \\
\hline Heterothalamus psiadioides & $\beta$-pinene, $\delta^{3}$-carene, and limonene & \multirow[t]{2}{*}{ Lactuca sativa and Allium cepa } & \multirow[t]{2}{*}{ [29] } \\
\hline Baccharis patens & linalool & & \\
\hline Senecio amplexicaulis & $\begin{array}{l}\alpha \text {-phellandrene, } o \text {-cymene and } \\
\beta \text {-ocimene }\end{array}$ & $\begin{array}{l}\text { Phalaris minor* and Triticum } \\
\text { aestivum }\end{array}$ & [47] \\
\hline Eucalyptus salubris & 1,8-cineole, $\alpha$-pinene and $p$-cymene & \multirow[t]{4}{*}{ Solanum elaeagnifolium * } & \multirow[t]{4}{*}{ [14] } \\
\hline Eucalyptus dundasii & $\begin{array}{l}\text { 1,8-cineole, } \alpha \text {-pinene and } \\
\text { trans-pinocarveol }\end{array}$ & & \\
\hline Eucalyptus spathulata & 1,8-cineole and $\alpha$-pinene & & \\
\hline Eucalyptus brockwayii & $\begin{array}{l}\alpha \text {-pinene, } 1,8 \text {-cineole and isopentyl } \\
\text { isovalerate }\end{array}$ & & \\
\hline Carum carvi & estragole, limonene, and $\beta$-pinene & $\begin{array}{l}\text { Raphanus sativus, Lactuca sativa, } \\
\text { and Lepidium sativum }\end{array}$ & [40] \\
\hline
\end{tabular}

${ }^{*}$ Reported as a weed.

Hydro-distilled EO from Senecio amplexicaulis with a high content of monoterpenes, including $\alpha$-phellandrene, $O$-cymene, and $\beta$-ocimene, reportedly exhibited strong allelopathic activity at higher concentrations, with a significant ability to inhibit germination of Phalaris minor and Triticum aestivum seeds [47]. The EOs of Heterothalamus psiadioides, composed mainly of the monoterpenes $\beta$-pinene, $\Delta 3$-carene, and limonene, showed cidal effects against Lactuca sativa and Allium cepa by inhibiting germination as well as growth of shoots and roots [29]. Moreover, a strong herbicidal activity against Amaranthus retroflexus, Chenopodium album, and Rumex crispus was reported in the EOs of the two Tanacetum species (T. aucheranum and T. chiliophyllum) by completely inhibiting seed germination and seedling growth, an ability that may be attributable to their monoterpene content, including 1,8-cineole, camphor, borneol, and terpinen-4-ol [46]. Significant reduction of seedling emergence and growth of Sinapis arvensis, Diplotaxis harra, Trifolium campestre, Desmazeria rigida, and Phalaris canariensis were reported via the EO derived from E. lehmanii in which monoterpenes represented the major constituents, including 1,8-cineole, $\alpha$-thujene, and $\alpha$-pinene [45].

The EOs from Agastache rugosa leaves collected over different seasons reportedly achieved partial or complete prevention of germination and growth of hypocotyl and radicles in Majorana hortensis, Trifolium repens, Rudbeckia hirta, Chrysanthemum zawadskii, Melissa officinalis, Taraxacum platycarpum, and Tagetes patula. These extracted EOs were described to be rich in the monoterpenes methylchavicol, $d$-limonene, and linalool as the main compounds [44]. In the same manner, the chemical profiles of the EOs of Chilean Peumus boldus and Drimys winterii were reported to be composed primarily of the monoterpenes ascaridole, $p$-cymene, and 1,8-cineole and $\gamma$-eudesmol, elemol, and terpinen-4-ol. These two EOs were found to exhibit inhibitory effects against Amaranthus hybridus and Portulaca oleracea [43]. The EO of Peumus boldus was found to inhibit germination and seedling growth in two weeds at all used concentrations, while Drimys winterii EO exhibited inhibitory activity against germination activity in Portulaca oleracea only at the highest dose $\left(1 \mu \mathrm{L} \mathrm{mL}^{-1}\right)$ [43]. In addition, de Oliveira, et al. [42] reported that different samples of EOs extracted by supercritical $\mathrm{CO}_{2}$ from Syzygium aromaticum at varying temperatures and pressures displayed allelopathic activities by inhibiting germination and radicle elongation in Mimosa pudica and Senna obtusifolia, with extraction of the EO at $50{ }^{\circ} \mathrm{C}$ and 300 bars associated with the most effective activity. The monoterpenes eugenol, eugenol acetate, and (E)-caryophyllene were reported as the main constituents of these samples. The EOs of the leaves and fruits of Shinus molle were reported to cause a concentration-dependent decline in the germination and radicle elongation of Triticum aestivum with more activity 
seen in leafy samples. Both oils were found to be composed of monoterpenes as the main components, with an abundance of $\beta$-phellendrene, $\alpha$-phellendrene, and myrcene [41].

The chemical components as well as the phytotoxic activities of EOs derived from 12 Mediterranean plants, including Hyssopus officinalis, Lavandula angustifolia, Ocimum basilicum, Majorana hortensis, Origanum vulgare, Salvia officinalis, Foeniculum vulgare, Thymus vulgaris, Melissa officinalis, Verbena officinalis, Pimpinella anisum, and Carum carvi, on germination and radicle growth in Raphanus sativus, Lactuca sativa, and Lepidium sativum seeds have been documented [40]. The EOs reportedly have an inhibitory effect against germination and initial radicle elongation at different doses through different mechanisms, with samples of Melissa officinalis, Thymus vulgaris, Verbena officinalis, and Carum carvi demonstrating the strongest effect. Monoterpenes were described as the main components of Hyssopus officinalis, Lavandula angustifolia, Majorana hortensis, Melissa officinalis, Ocimum basilicum, Origanum vulgare, Salvia officinalis, Thymusvulgaris, Verbena officinalis, and Carum carvi, while non-terpenoid phenols were the main constituents in Foeniculum vulgare and Pimpinella anisum [40]. Similarly, peppermint EO is reportedly rich in menthone, menthol, and menthofuran, and has been described as having a potent allelopathic effect on seed germination and seedling growth in Lycopersicon esculentum, Raphanus sativus, Convolvulus arvensis, Portulaca oleracea, and Echinochloa colonum [39]. In 2010, the main components of Zataria multiflora $\mathrm{EO}$ were reported as the monoterpenes carvacrol, linalool, and $p$-cymene, all of which exhibited significant herbicidal activities against Hordeum spontaneum, Secale cereal, Amaranthus retroflexus, and Cynodon dactylon [38]. This activity was associated with significant inhibition of the rate of germination, seedling length, root and stem fresh and dry weights at all used concentrations, and 320 and $640 \mathrm{~mL} \mathrm{~L}^{-1}$ in particular [38].

The dose-dependent toxicity of the EOs of Cotinus coggyria, which consist mainly of monoterpenes such as limonene, $\alpha$-pinene, and $\beta$-myrcene, against the weeds of Silybum marianum and Portulaca oleracea reportedly [37] decreased germination in radishes by $83 \%$ and $60 \%$, seedling radicle length by $93 \%$ and $84 \%$, and plumule length by $84 \%$ and $91 \%$ at $32 \mu \mathrm{L} \mathrm{mL}^{-1}$. The EOs of Pinus brutia and Pinus pinea were documented to have monoterpenes as the major components, with a preponderance of $\alpha$-and $\beta$-pinene and caryophyllene [35]. At higher dose, these EOs were found to have a potent inhibitory effect on germination by $53 \%$ and $22 \%$ of Lactuca sativa, $60 \%$ and $33 \%$ of Lepidium sativum, and $13 \%$ and $3 \%$ of Portulaca oleracea, respectively [35]. An evaluation of Tunisian Pinus pinea EO, rich in limonene, $\alpha$ - and $\beta$-pinene, revealed a dose-related gradual inhibition of Lolium rigidum, Sinapis arvensis, and Raphanus raphanistrum, and seed germination was completely inhibited at low concentrations [36]. The EO of Plectranthus amboinicus, which is composed primarily of monoterpenes, and carvacrol in particular $(88.61 \%)$, was reported to significantly inhibit germination and reduce the growth of Lactuca sativa and Sorghum bicolor roots and shoots [34]. Another study [33] described the EO chemical composition of two Eucalyptus plants in which monoterpenes, including p-cymene, $\beta$-myrcene, and (+)-limonene, were the main components in Eucalyptus grandis, and $\alpha$-pinene, $\gamma$-terpinene, and $p$-cymene in E. citriodora. These EOs were found to dose-dependently inhibit germination of Lactuca sativa, with a concentration of $0.1 \mu \mathrm{L} \mathrm{mL}^{-1}$ of both oils suppressing germination by $74 \%$ and $68 \%$, respectively [33].

With a preponderance of the monoterpenoids $p$-cymene, $\beta$-myrcene, and (+)-limonene, along with acenaphthene, EO extracted from Artemisia scoparia was found to have significant phytotoxic activities, primarliy against the roots of Achyranthes aspera, Cassia occidentalis, Echinochloa crus-galli, Ageratum conyzoides, and Parthenium hysterophorus [32] with the latter species suffering the most effects [32]. In the same manner, an artemisia ketone-rich EO derived from Eucalyptus africanus reportedly exhibited a potent effect similar to that of Eucalyptus camaldulensis on Amaranthus hybridus, but without a noticeable effect on Portulaca oleracea [23].

The phytotoxic activity of the EO of the Turkish Origanum acutidens and its monoterpenoid components (carvacrol, $p$-cymene, and thymol) were studied by Kordali, et al. [22]. Their results revealed that carvacrol and thymol completely inhibited seed germination 
and seedling growth in Chenopodium album, Amaranthus retroflexus, and Rumex crispus, but no effect was observed with $p$-cymene [22]. The EO of Cymbopogon citratus, which is composed mostly of the monoterpenes neral, geranial, and $\beta$-myrcene, was reported to delay the germination of seeds and inhibit seedling growth in Echinochloa crus-galli [21]. In another study, the EOs of the aerial parts of four plants-Cymbopogon citratus, Origanum vulgare, Eucalyptus cladocalyx, and Artemisia absinthium - were determined to be potential bioherbicides against the seeds of Sinapis arvensis, with the EOs of Cymbopogon citratus and Eucalyptus cladocalyx [20] exhibiting the most activity. Neral, geranial, and $\alpha$-pinene, along with other monoterpenes, were found to be the main components of Cymbopogon citratus. However, the sesquiterpene spathulenol, as well as the monoterpenes 1,8-cineole and $p$-cymene, were found to be the main components of the EO of Eucalyptus cladocalyx. The three monoterpenoids carvacrol, $\gamma$-terpinene, and $p$-cymene were described as major constituents of the EO of Origanum vulgare, while Artemisia absinthium EO was reported to be composed largely of monoterpenes, including $\beta$-thujone, chamazulene, and linalool [20].

Potential herbicidal activity of the EO from Nepeta flavida was reported against Raphanus sativus, Lepidium sativum, and Eruca sativa, in which it completely inhibited germination at a concentration of $4.0 \mu \mathrm{L} \mathrm{mL}^{-1}$ [28], an effect that may be attributed to the presence of the monoterpenes linalool, 1,8-cineole, and sabinene [28]. Monoterpenes including carvacrol, $\gamma$-terpinene, $p$-cymene were found to be the predominant constituents of the EO of Thymbra spicata and may be responsible for the strong phytotoxic activity reported against Zea mays, Triticum aestivum, Lactuca sativa, Lepidium sativum, and Portulaca oleracea [27]. Ulukanli, et al. [26] reported that the EO of Thymus eigii exhibited significant toxic effects against Lepidium sativum, Lactuca sativa, and P. oleracea. This oil was found to be rich with monoterpenes, with thymol, carvacrol, and $p$-cymene the major constituents [26]. Moreover, EOs extracted from Thymus daenensis collected from four different habitats inhibited germination in Avena fatua, Amaranthus retroflexus, Datura stramonium, and Lepidium sativum. These four ecospecies of Thymus daenensis were found to be rich with monoterpenoids, including thymol, carvacrol, and p-cymene in particular [25].

Foliar volatiles of Callistemon viminalis and EOs reportedly reduced seed germination, seedling growth, and accumulation of dry matter in Bidens pilosa, Cassia occidentalis, Echinochloa crusgalli, and Phalaris minor, with the greatest sensitivity observed in B. pilosa [19]. Monoterpenoids, and 1,8-cineole, $\alpha$-pinene, and $d$-limonene in particular, have been described as major components in the EO of this plant. Pinheiro, et al. [17] reported an allelopathic effect of the EO extracted from Cannabis sativa on germination and seedling growth in Amaranthus retroflexus, Bromus secalinus, Avena sativa, and Brassica oleracea. Based on gas chromatography-mass spectroscopy analysis, this oil is rich in monoterpenes, including myrcene, terpinolene, and (E)- $\beta$-Ocimene [18].

Monoterpene-rich EOs derived from Schinus terebinthifolius collected from two different areas of Brazil reportedly produced an inhibitory effect on germination, root and hypocotyl growth, and production of biomass in Bidens pilosa. In the Cerrado biome, the EO of Schinus terebinthifolius was found to be rich with trans-caryophyllene, 3-carene, and germacrene B, while Schinus terebinthifolius from the country's Atlantic forest biome is rich with $\alpha$-pinene, limonene, and $\beta$-pinene [17]. Additionally, the $\mathrm{EO}$ of Vitex agnus-castus was reported to be rich with monoterpenes, particularly 1,8-cineole, sabinene, trans- $\beta$-farnesene, and $\alpha$-pinene. This EO was found to exhibit significant inhibitory activity on Lactuca sativa and Lepidium sativum [24].

The EO of Salvia sclarea was described to have significant phytotoxic effects against Lepidium sativum, Lactuca sativa, and Portulaca oleracea at a concentration of $0.16 \mathrm{mg} \mathrm{mL}^{-1}$, reducing seed germination by $94 \%, 100 \%$, and $50 \%$, respectively [16]. The main constituent of this EO was reported to be monoterpenes, including L-linalool, linalyl acetate, $\alpha$-terpineol, and geraniol [16].

The EO from the aerial parts of Euphorbia heterophylla reportedly inhibited germination (93.9\%), root (84.6\%), and shoot growth (57.8\%) in Cenchrus echinatus weeds at $100 \mu \mathrm{L} \mathrm{L}^{-1}$. 
The authors described monoterpenes as the major components (69.48 \%), and 1,8-cineole was the primary monoterpene, representing $32.03 \%$ of the total mass [6].

\section{Monoterpene-Rich EO-Allelopathy Correlation}

Application of a PCA to a dataset of the 46 different plant species with EOs comprised mainly of monoterpenes found allelopathic activity is presented in Figure 1. The results show that that $\alpha$ - and $\beta$-pinene, 1,8 cineole, linalool, and carvacrol were the most effective allelopathic monoterpene compounds. They also showed that Eucalyptus africanus, Origanum acutidens, Zataria multiflora, and Plectranthus amboinicus were correlated to each other linalool and carvacrol predominating (Figure 1). Meanwhile, Pinus brutia, Schinus terebinthifolius, Thymus vulgaris, Eucalyptus lehmanii, Eucalyptus lehmanii, Eucalyptus lehmanii, Callistemon viminalis, Majorana hortensis, Vitex agnus-castus, and Eucalyptus brockwayii showed a close correlation with each other with respect to the composition of their EOs; 1,8 -cineole and $\alpha$, and $\beta$-pinene were the major monoterpenoid compounds. The analysis found $\alpha-$, and $\beta$-pinene and 1,8 cineole in most of the allelopathic plants in which monoterpenes are major $\mathrm{EO}$ compounds.

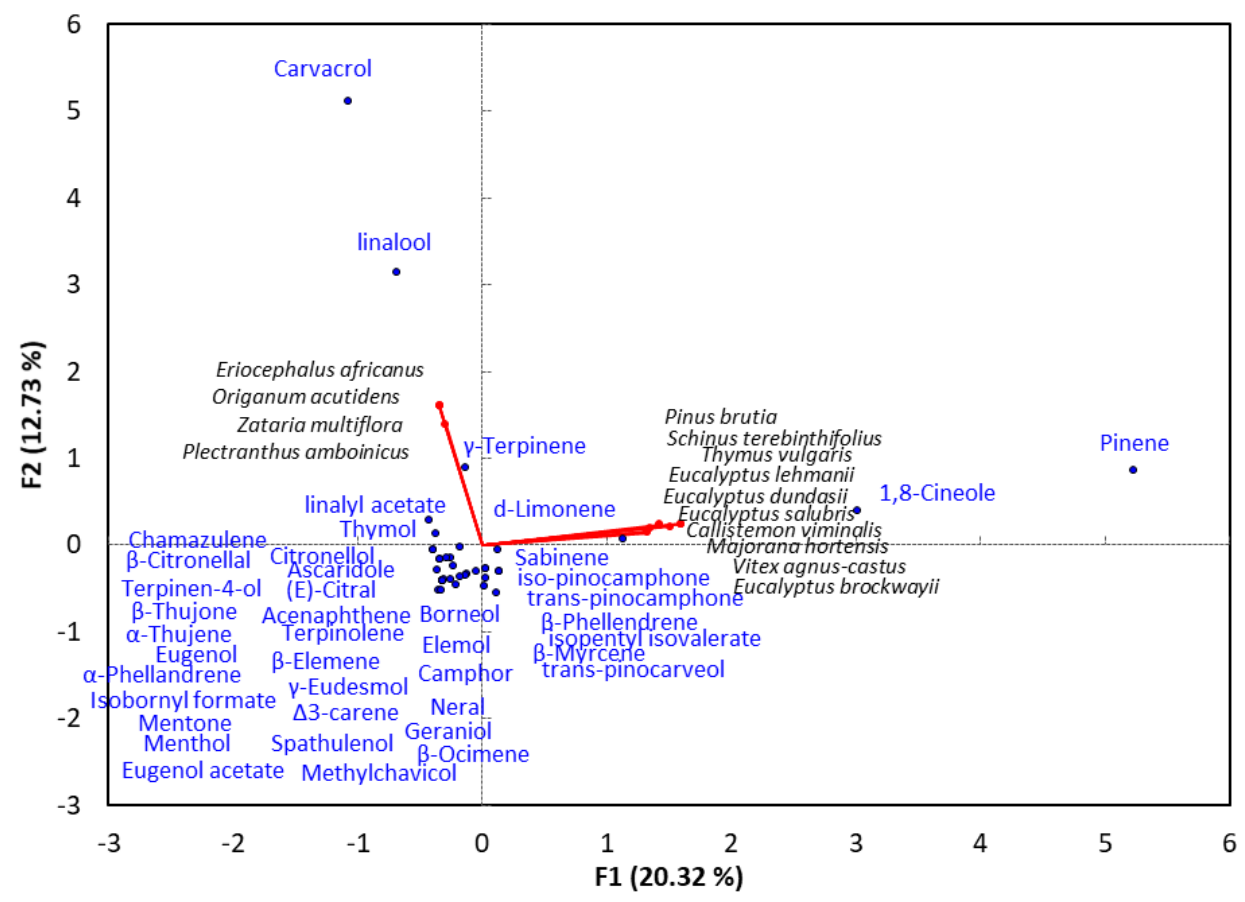

Figure 1. Principal component analysis of reported plants with essential oils containing monoterpenes as major compounds and showing allelopathic activity.

\section{Phytotoxic EOs Derived from Plants Rich in Sesquiterpenes}

Sesquiterpene-rich EOs from different plants associated with notable phytotoxic activities are listed in Table 2. The EO of Eupatorium adenophorum was described as being composed primarily of sesquiterpenes, with $\gamma$-cadinene, $\gamma$-muurolene, and 3-acetoxyamorpha4,7(11)-diene-8-one as the main compounds. This oil reportedly exhibited strong phytotoxic activity against Phalaris minor and Triticum aestivum, with a stronger effect observed against Phalaris minor [48]. Elshamy and his co-workers reported the EO composition and allelopathic activities of three Launaea plants (Launaea mucronata, Launaea nudicaulis, and Launaea spinosa) collected from different habitats. Results showed that these EOs had significant and concentration-dependent effects on Portulaca oleracea weeds. The EOs of two samples of Launaea mucronata collected from the desert and coastal regions were found to have the highest activity, inhibiting germination by $96.1 \%$ and $87.9 \%$ and radicle growth by $92.6 \%$ and $89.7 \%$, respectively, at $250 \mu \mathrm{L} \mathrm{L}^{-1}$ [6]. The authors found that sesquiterpenes were the main components, and hexahydrofarnesyl acetone the main compound, in Launaea 
mucronata [6]. The EO of Schinus lentiscifolius was reported to be associated with a 19.35\% reduction in the mitotic index in onions and $25.14 \%$ in lettuce, compared with negative control. This EO was found to comprise sesquiterpenoid compounds as the main components, and $\delta$-cadinene in particular [49].

Table 2. Sesquiterpene-rich EOs derived from various plants and exhibiting phytotoxic activity.

\begin{tabular}{|c|c|c|c|}
\hline Plant Name & Major Sesquiterpenes Compounds & Phytotoxic Against & Reference \\
\hline Lactuca serriola & isoshyobunone, and alloaromadendrene oxide-1 & Bidens pilosa * & [7] \\
\hline Launaea mucronata & hexahydrofarnesyl acetone and (-)-spathulenol & \multirow[t]{3}{*}{ Portulaca oleracea * } & \multirow{3}{*}[6]{} \\
\hline Launaea nudicaulis & $\begin{array}{l}\text { hexahydrofarnesyl acetone and } \gamma \text {-gurjunen } \\
\text { epoxide (2) }\end{array}$ & & \\
\hline Launaea spinosa & $\begin{array}{l}\alpha \text {-acorenol, trans-longipinocarveol, } \\
\text { and } \gamma \text {-eudesmol }\end{array}$ & & \\
\hline Heliotropium curassavicum & $\begin{array}{l}\text { Hexahydrofarnesyl acetone, (-)-caryophyllene } \\
\text { oxide, farnesyl acetone }\end{array}$ & Chenopodium murale* & [6] \\
\hline Xanthium strumarium & $\alpha$-eudesmol, (-)-spathulenol, and ledene alcohol & Bidens pilosa * & [3] \\
\hline Cullen plicata & $\begin{array}{l}\text { (-)-caryophyllene oxide, z-nerolidol, tau.cadinol } \\
\text { and } \alpha \text {-cadinol }\end{array}$ & $\begin{array}{l}\text { Bidens pilosa * and Urospermum } \\
\text { picroides * }\end{array}$ & {$[50]$} \\
\hline Scutellaria strigillosa & $\begin{array}{l}\text { germacrene } \mathrm{D} \text {, bicyclogermacrene, } \\
\text { and } \beta \text {-caryophyllene }\end{array}$ & $\begin{array}{l}\text { Amaranthus retroflexus * and } \\
\text { Poa annua* }\end{array}$ & [51] \\
\hline Acroptilon repens & $\begin{array}{l}\text { caryophyllene oxide, } \beta \text {-cubebene, } \\
\beta \text {-caeyophyllen, and } \alpha \text {-copaen }\end{array}$ & $\begin{array}{l}\text { Amaranthus } \\
\text { retroflexus }{ }^{*} \text { and Cardaria draba } \\
\text { * }\end{array}$ & {$[52]$} \\
\hline Lantana camara & $\begin{array}{l}\alpha \text {-curcumene, } \beta \text {-caryophyllene, } \\
\text { and } \gamma \text {-curcumene }\end{array}$ & \multirow[t]{2}{*}{$\begin{array}{l}\text { Amaranthus hybridus * and } \\
\text { Portulaca oleracea * }\end{array}$} & \multirow[t]{3}{*}[23]{} \\
\hline Eucalyptus camaldulensis & spathulenol, and isobicyclogermacrenal & & \\
\hline Eupatorium adenophorum & $\begin{array}{l}\gamma \text {-cadinene, } \gamma \text {-muurolene, } \\
\text { and 3-acetoxyamorpha-4,7(11)-diene-8-one }\end{array}$ & $\begin{array}{l}\text { Phalaris minor* and Triticum } \\
\text { aestivum * }\end{array}$ & \\
\hline Baccharis patens & $\beta$-caryophyllene, and spathulenol & Lactuca sativa and Allium cepa & [29] \\
\hline Salvia multicaulis & $\begin{array}{l}\alpha \text {-Copaene, } \beta \text {-caryophyllene, } \\
\text { and aromadendrene }\end{array}$ & \multirow[t]{7}{*}{$\begin{array}{l}\text { Raphanus sativus and Lepidium } \\
\text { sativum }\end{array}$} & \multirow{5}{*}[40]{} \\
\hline Teucrium arduini & $\begin{array}{l}\text { caryophyllene, caryophyllene oxide, germacrene } \\
\text { D, and spathulenol }\end{array}$ & & \\
\hline Teucrium maghrebinum & $\begin{array}{l}\text { germacrene } \mathrm{d}, \delta \text {-cadinene, } \gamma \text {-cadinene, } \\
\text { and caryophyllene }\end{array}$ & & \\
\hline Teucrium polium & caryophyllene, torreyol, and $\alpha$-cadinol & & \\
\hline Teucrium montbretii & $\begin{array}{l}\text { carvacrol, caryophyllene, and caryophyllene } \\
\text { oxide }\end{array}$ & & \\
\hline Nepeta curviflora & $\begin{array}{l}\beta \text {-caryophyllene, caryophyllene oxide, } \\
\text { and }(E)-\beta \text {-farnesene }\end{array}$ & & \multirow[t]{2}{*}[31]{} \\
\hline Nepeta nuda & $\beta$-bisabolene & & \\
\hline Ailanthus altissima & $\begin{array}{l}\beta \text {-caryophyllene, }(Z) \text {-caryophyllene, } \\
\text { and germacrene } D,\end{array}$ & \multirow[t]{2}{*}{ Lactuca sativa } & {$[53]$} \\
\hline Schinus lentiscifolius & $\delta$-cadinene, $\alpha$-cadinol, and $\beta$-caryophyllene & & {$[49]$} \\
\hline Pulicaria somalensis & $\begin{array}{l}\text { Juniper camphor }(24.7 \%), \alpha \text {-sinensal }(7.7 \%) \text {, } \\
\text { 6-epi-shyobunol }(6.6 \%) \text {, and } \alpha \text {-zingiberene }(5.8 \%)\end{array}$ & $\begin{array}{l}\text { Dactyloctenium aegyptium * } \\
\text { and Bidens pilosa * }\end{array}$ & {$[4]$} \\
\hline Bassia muricata & hexahydrofarnesyl acetone, and $\alpha$-gurjunene & Chenopodium murale* & [54] \\
\hline
\end{tabular}

\footnotetext{
* Reported as a weed.
} 
A study of the chemical profiles of EOs of Tunisian Ailanthus altissima [53] deduced the presence of a high concentration of sesquiterpenes such as $\beta$-caryophyllene, (Z)caryophyllene, germacrene $\mathrm{D}$, and hexahydrofarnesyl acetone. The phytotoxic activities of the EOs (at a concentration of $1 \mathrm{mg} \mathrm{mL}^{-1}$ ) of the roots, stems, leaves, flowers, and fruits completely inhibited seed germination in Lactuca sativa [53]. Raphanus sativus and Lepidium sativum root growth was reduced under the effects of the EOs of Nepeta curviflora and Nepeta nuda. These EOs were found to have sesquiterpenes, and $\beta$-caryophyllene, caryophyllene oxide, and $\beta$-bisabolene in particular, as the main components. [31]. In addition, the EOs of Teucrium maghrebinum, Teucrium polium, and Teucrium montbretii were reported to be rich sources of sesquiterpenes, including caryophyllene, caryophyllene oxide, and carvacrol in particular. These EOs were found to significantly reduce the radicle growth of Raphanus satious and Lepidium sativum with mild effect on germination [55].

The herbicidal effects of the EOs derived from Lantana camara, Eucalyptus camaldulensis, and Eriocephalus africanus were determined by Verdeguer, et al. [23]. The EO of Eucalyptus camaldulensis, which is reportedly composed primarily of spathulenol, had the greatest impact among the three plants, completely inhibiting seedling growth and germination in Amaranthus hybridus and Portulaca oleracea. With a high concentration of sesquiterpenes, and sesquiterpene hydrocarbons in particular. The EO of Lantana camara reportedly exhibited significant allelopathic activity against Amaranthus hybridus [23]. Recently, Elshamy, et al. [7] reported significant allelopathic effects of Lactuca serriola EO against Bidens pilosa, with half-maximal inhibitory concentrations $\left(\mathrm{IC}_{50}\right)$ of $104.3,92.3$, and $140.3 \mu \mathrm{L} \mathrm{L}^{-1}$ for germination, growth of roots, and growth of shoots, respectively. The EO of Lactuca serriola was described to be rich with sesquiterpenes, with isoshyobunone and alloaromadendrene oxide- 1 as major components. The EO of the invasive noxious plant Heliotropium curassavicum, collected from an inland area, demonstrated remarkable phytotoxic activities against Chenopodium murale, with $\mathrm{IC}_{50}$ values of $2.66,0.59$, and $0.70 \mathrm{mg} \mathrm{mL}^{-1}$ for germination, growth of roots, and growth of shoots, respectively. A coastal sample of the same species exhibited more allelopathic activity, with $\mathrm{IC}_{50}$ values of $1.58,0.45$, and $0.66 \mathrm{mg} \mathrm{mL}^{-1}$ [7]. Sesquiterpenes were determined to be the main class of EOs of Heliotropium curassavicum, and hexahydrofarnesyl acetone, (-)-caryophyllene oxide, and farnesyl acetone were the major compounds. In 2019, Abd El-Gawad and his co-authors reported that EOs from the leaves of the Egyptian Xanthium strumarium exhibited allelopathic effects against Bidens pilosa, and a concentration of $1000 \mu \mathrm{L} \mathrm{L}^{-1}$ inhibited seed, root, and shoot germination growth by $97.34 \%, 98.45 \%$, and $93.56 \%$, respectively [3]. In the EO of Xanthium strumarium, the sesquiterpenoids 1,5-dimethyltetralin, eudesmol, and l-borneol were the major identified compounds.

The EO of Symphyotrichum squamatum collected from Egypt was analyzed and found to be enriched in sesquiterpenes such as humulene, epoxide, (-)-spathulenol, and (-)caryophyllene oxide [15]. The EO of this plant was reported to have a strong and concentration -dependent allelopathic effect against Bidens pilosa weeds. The EO of Cullen plicata, rich in sesquiterpenes such as (-)-caryophylleneoxide, Z-nerolidol, tau cadinol, and $\alpha$-cadinol, was reported to completely inhibit germination in Bidens pilosa and Urospermum picroides at $200 \mu \mathrm{L} \mathrm{L}_{-1}$ with respective $\mathrm{IC}_{50}$ values of 49.39 and $17.86 \mu \mathrm{L} \mathrm{L}^{-1}$ [50]. The EO derived from Scutellaria strigillosa was found to have significant phytotoxic potential against Amaranthus retroflexus and Poa annua [51]. These weeds were inhibited by $86.6 \%$ and $20.0 \%$, respectively, when treated with $1 \mu \mathrm{L} \mathrm{ml}^{-1}$ of Scutellaria strigillosa EOs. This active EO was found to be rich in sesquiterpenes, and germacrene D, 1-octen-3-ol, bicyclogermacrene, and $\beta$-caryophyllene in particular. In another study, the extracted EO of Acroptilon repes was examined by Razavi, et al. [52] for its phytotoxic activity against Amaranthus retroflexus and Cardaria draba. They reported that EOs from Acroptilon repes had a significant inhibitory effect on seed germination in Amaranthus retroflexus. Sesquiterpenes including caryophyllene oxide, $\beta$-cubebene, $\beta$-caeyophyllen, and $\alpha$-copaen were reported as the main constituents of this EO [52]. 
Recently, Assaeed et al. reported that sesquiterpene-rich EOs of the aerial parts of Pulicaria somalensis had significant phytotoxic effects on the weeds of Dactyloctenium aegyptium and Bidens poilosa, with an $\mathrm{IC}_{50}$ of $0.6 \mathrm{mg} \mathrm{mL}^{-1}$ for root growth in both weeds, and 0.7 and $1.0 \mathrm{mg} \mathrm{mL}^{-1}$ for shoot growth, respectively. Juniper camphor $(24.7 \%), \alpha-$ sinensal (7.7\%), 6-epi-shyobunol (6.6\%), and $\alpha$-zingiberene (5.8\%) were reported to be the main chemical constituents of the EO of this plant [54].

Lastly, the EO of aboveground parts of Bassia muricata (Chenopodiaceae) was found to have a significant reduction effect on root growth, shoot growth, and germination in Chenopodium murale weed, with $\mathrm{IC}_{50}$ values of $175.60 \mu \mathrm{L} \mathrm{L}^{-1}, 246.65 \mu \mathrm{L} \mathrm{L}^{-1}$, and $308.33 \mu \mathrm{L}$ $\mathrm{L}^{-1}$, respectively. Sesquiterpenes were found to be the main constituents of the EO, with an abundance of hexahydrofarnesyl acetone, and $\alpha$-gurjunene [54].

\section{Sesquiterpene-Rich EO-Allelopathy Correlation}

The application of PCA to a dataset of 15 different plant species with EOs composed mainly of sesquiterpenoid compounds showed allelopathic activity is presented in Figure 2. Caryophyllene, caryophyllene oxide, germacrene D, spathulenol, and hexahydrofarnesyl acetone were the sesquiterpenoids most associated with allelopathic activity. Most tested plant species were correlated to each other regarding these major EO compounds.

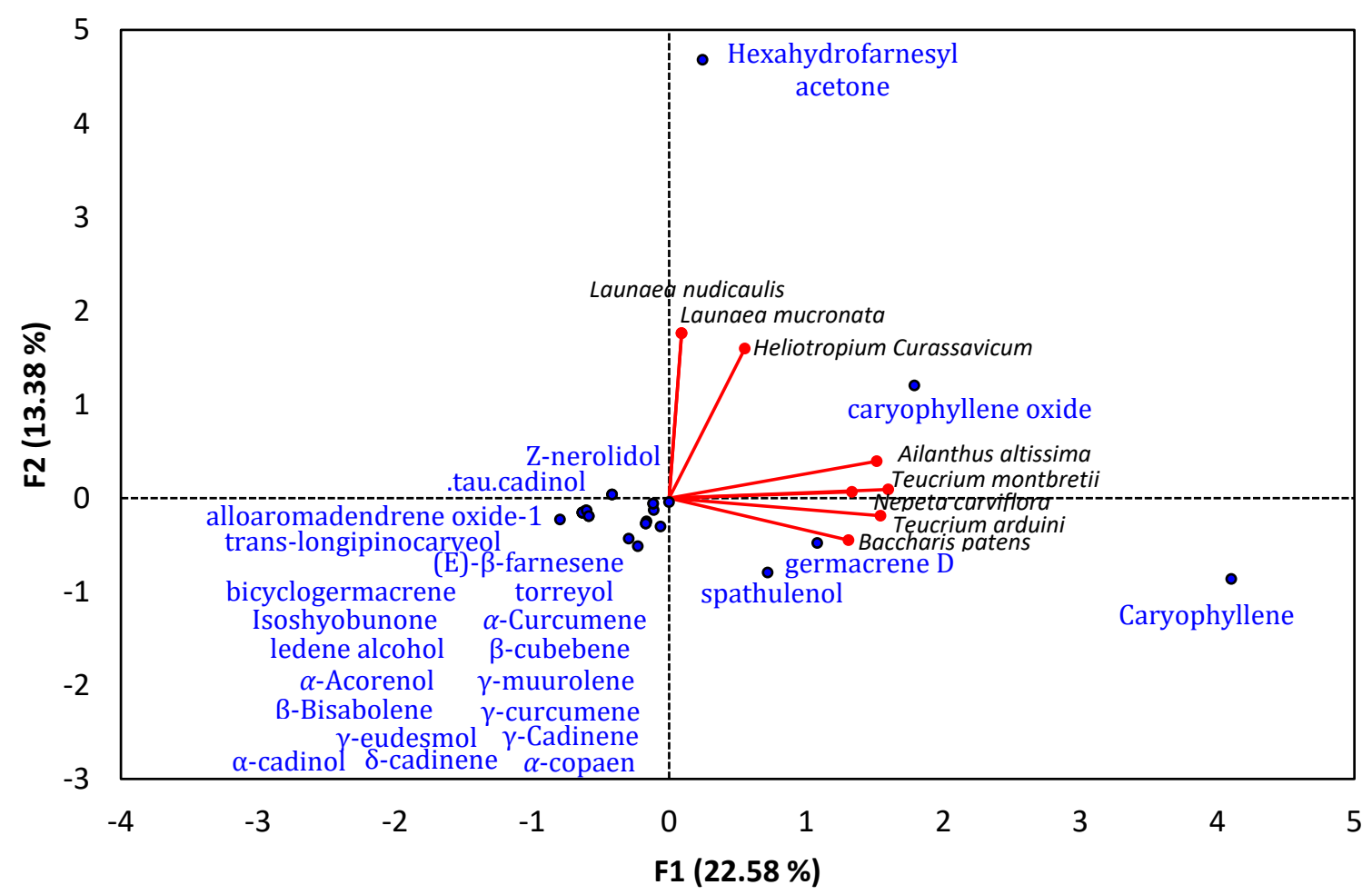

Figure 2. Principal component analysis of reported plants with essential oils containing sesquiterpenes as major compounds and showing allelopathic activity.

\section{Phytotoxic EOs Derived from Plants Rich in Non-Terpenoids}

Phytotoxic EOs with non-terpenoid major compounds are listed in Table 3. The EOs of leaves and fruits of Ecballium elaterium reportedly contain phenolics and hydrocarbons, including E-anethol, octyl octanoate, 3-(6,6-dimethyl-5-oxohept-2-enyl)-cyclohexanone, and tetracosane as major components [56]. The $\mathrm{EO}$ of the leaves was found to have an allelopathic effect on Lactuca sativa that was stronger than that of fruits, with a significant $(12 \%)$ decrease in seed germination. In another study, Mutlu, et al. [57] found that EO rich in iridoids from Nepeta meyeri had a strong inhibitory effect $(>50 \%)$ on seed germination of 
Bromus danthoniae, Bromus intermedius, and Lactuca serriola at a concentration of $0.01 \%$ and $0.02 \%$. Kordali, et al. [58] reported that the EO of the Turkish plant Nepeta meyeri contained $4 a-\alpha, 7-\alpha, 7 a-\beta$ nepetalactone and $4 a-\alpha, 7-\alpha, 7 a-\alpha$ nepetalactone as major compounds. This EO completely inhibited germination of Amaranthus retroflexus, Chenopodium album, Cirsium arvense, and Sinapsis arvensis at a concentration of $0.5 \mathrm{mg} \mathrm{mL}^{-1}$. Iridoids, and $4 \mathrm{a}-\alpha, 7-\alpha, 7 \mathrm{a}-$ $\beta$-nepetalactone and $4 \mathrm{a}-\alpha, 7-\beta, 7 \mathrm{a}-\alpha$-nepetalactone in particular, were determined to be the major compounds of the EO of Nepeta cataria [59]. This EO can reportedly act as an allelochemical agent against Hordeum spontaneum, Taraxacum officinale, Avena fatua, and Lipidium sativum, with dose-dependent suppression of germination [59]. Similarly, Bozok, et al. [60] reported a strong herbicidal activity for the EO of Nepeta nuda on germination and seedling growth in Raphanus sativus, Triticum aestivum, Lactuca sativa, Portulaca oleracea, and Lepidium sativum. This EO was rich in iridoids $4 \mathrm{a}-\alpha, 7-\alpha, 7 \alpha-\beta$-nepetalactone, $2(1 \mathrm{H})$-naphthalenone, and trans-octahydro-8a-methyl. Finally, Mancini, et al. [31] reported that the EOs of the two Salvia species (Salvia hierosolymitana and Salvia multicaulis) displayed phytotoxic effects on Raphanus sativus by reducing radicle elongation and seed germination. These EOs are characterized by an abundance of carbonylic compounds.

Table 3. Nonterpenoidial-rich EOs derived from plants and with significant phytotoxic activity.

\begin{tabular}{|c|c|c|c|c|}
\hline Plant Name & Main Components & Major Compounds & Phytotoxic Against & Reference \\
\hline Nepeta nuda & Iridoids & $\begin{array}{l}\text { 4a- } \alpha, 7-\alpha, 7 \mathrm{a}-\beta- \\
\text { nepetalactone, } \\
2(1 \mathrm{~h}) \text {-naphthalenone, } \\
\text { and octahydro-8a- } \\
\text { methyl-trans- }\end{array}$ & $\begin{array}{l}\text { Triticum aestioum, Raphanus } \\
\text { satious, Lactuca sativa, } \\
\text { Lepidium satioum, } \\
\text { and Portulaca oleracea * }\end{array}$ & {$[60]$} \\
\hline Nepeta cataria & Iridoids & $\begin{array}{l}4 \mathrm{a}-\alpha, 7-\alpha, 7 \mathrm{a}-\beta- \\
\text { nepetalactone and } \\
4 \mathrm{a}-\alpha, 7-\beta, 7 \mathrm{a}-\alpha- \\
\text { nepetalactone }\end{array}$ & $\begin{array}{l}\text { Hordeum spontaneum *, } \\
\text { Taraxacum officinale *, Avena } \\
\text { fatua }^{*} \text {, and Lipidium } \\
\text { sativum }\end{array}$ & {$[59]$} \\
\hline Nepeta meyeri & Iridoids & $\begin{array}{l}4 \mathrm{a}-\alpha, 7-\alpha, 7 \mathrm{a}-\beta- \\
\text { nepetalactone and } \\
4 \mathrm{a}-\alpha, 7-\beta, 7 \mathrm{a}-\alpha- \\
\text { nepetalactone }\end{array}$ & $\begin{array}{l}\text { Amaranthus } \\
\text { retroflexus *, Bromus } \\
\text { danthoniae *, Bromus } \\
\text { intermedius *, Chenopodium } \\
\text { album *, Cynodon dactylon *, } \\
\text { Lactuca serriola *, Portulaca } \\
\text { oleracea }{ }^{*}, \text { Cirsium arvense } \\
\text { and Sinapsis arvensis * }\end{array}$ & {$[57,58]$} \\
\hline $\begin{array}{l}\text { Ecballium } \\
\text { elaterium }\end{array}$ & $\begin{array}{l}\text { Phenolics and } \\
\text { hydrocarbons }\end{array}$ & $\begin{array}{l}e \text {-anethol, octyl } \\
\text { octanoate, 3-(6,6- } \\
\text { dimethyl-5-oxohept-2- } \\
\text { enyl)-cyclohexanone, } \\
\text { and tetracosane }\end{array}$ & Lactuca sativa & {$[56]$} \\
\hline Pimpinella anisum & Non-terpenoidial phenols & cis-anethole & \multirow{2}{*}{$\begin{array}{l}\text { Raphanus sativus, Lactuca } \\
\text { sativa, and Lepidium sativum }\end{array}$} & \multirow{2}{*}[40]{} \\
\hline $\begin{array}{l}\text { Foeniculum } \\
\text { vulgare }\end{array}$ & Non-terpenoidial phenols & cis-anethole & & \\
\hline
\end{tabular}

* Reported as a weed.

\section{Structure-Activity Relationship Summary}

Based on the data presented in Tables 1-3 and correlation analysis between phytotoxic EOs derived from different plants and their major chemical constituents (Figures 1 and 2), we concluded that the phytotoxic activities of EOs increase with terpenoid content, particularly oxygenated terpenoid content. Almost all previous studies found that increasing the oxygenation of terpenoids led to an increase in allopathic activities via inhibition of germination and growth of noxious weeds $[6,16,23]$. 
As can be seen in Table 1, oxygenated monoterpenoids are the main components of phytotoxic EOs, and their phytotoxicity was observed to increase with the degree of oxygenation. For example, the mono-oxygenated monoterpenoid 1,8-cineole (eucalyptol, $\mathrm{C}_{10} \mathrm{H}_{18} \mathrm{O}$ ), was to be the main compound in several allopathic EOs derived from plants from different botanical families such as Euphorbia heterophylla [6], Callistemon viminalis [19], Eucalyptus cladocalyx [20], Nepeta flavida [28], Majorana hortensis [40], Peumus boldus [43], Eucalyptus lehmanii [45], Tanacetum aucheranum, Tanacetum chiliophyllum [46], Eucalyptus salubris, Eucalyptus brockwayii, and Eucalyptus dundasii [14].

In addition, linalool and borneol were found to be the major compounds in numerous phytotoxic oils, such as Salvia sclarea [16], Artemisia absinthium [20], Origanum acutidens [22], Eriocephalus africanus [23], Nepeta flavida [28], Zataria multiflora [38], Agastache rugosa [44], Salvia officinalis, and Ocimum basilicum [40], and Tanacetum chiliophyllum [46]. It is therefore clear that the oxygenated monoterpenoids 1,8-cineole, linalool, and borneol play significant and effective roles as allopathic agents and more research into their phytotoxic activity and phytotoxic mechanism(s) is recommended.

Similarly, careful analysis of sesquiterpene-rich phytotoxic EOs revealed that an increase in oxygenated sesquiterpene levels can enhance the phytotoxic activity of an EO. The data supplied in Table 2 and PCA analysis suggest the major oxygenated sesquiterpenes caryophyllene and its derivatives, as well as hexahydrofarnesyl acetone, can be potent phytotoxic agents. The phytotoxic EOs derived from Baccharis patens [29,30], Heliotropium curassavicum [7], Cullen plicata [50], Scutellaria strigillosa [51], Acroptilon repens [52], Lantana camara [23], Teucrium arduini, Teucrium maghrebinum, Teucrium polium, Teucrium montbretii [31], and Ailanthus altissima [53] were reported to have all or one of $\beta$-caryophyllene, (-)-caryophyllene, and caryophyllene oxide as primary compounds. These reports indicate a strong correlation between the phytotoxic activities of EOs and the presence of these compounds as main components. Hexahydrofarnesyl acetone has been described as an essential compound in the phytotoxic EOs of Launaea mucronata, Launaea nudicaulis [6], Heliotropium curassavicum [7], and Ailanthus altissima [53]. The authors of these studies also concluded that compounds with hexahydrofarnesyl acetone as a main constituent can play a major role as phytotoxic mediators.

EOs derived from aromatic plants typically consist of low-molecular-weight terpenoids, including mono, sesqui-, and diterpenoids as well as non-terpenoid components [14]. Two plants belonging to the Nepeta genus were reported that containing iridoid-rich EOs such as Nepeta meyeri $[57,58]$ and Nepeta cataria [59]. The two iridoids $4 a-\alpha, 7-\alpha, 7 a-\beta$-nepetalactone and $4 a-\alpha, 7-\beta, 7 a-\alpha$-nepetalactone were reported to be the main phytotoxic mediators in the EOs of these two species. The two compounds should, therefore, be subjected to further study to evaluate their allopathic abilities against several noxious weeds.

Author Contributions: A.I.E. and A.M.A.-E. contributed to the conceptualization, data collection, analysis of data, visualization, and writing of the first draft of the manuscript. A.I.E., A.M.A.-E., A.E.N.G.E.G., A.M.A., S.L.A.-R., A.S.A., T.A.M., M.I.N., and Y.H.D. contributed to writing-review and editing of the manuscript. All authors discussed the results, commented on the paper, and approved the final manuscript. All authors have read and agreed to the published version of the manuscript.

Funding: This research was funded by Deputyship for Research \& Innovation, "Ministry of Education" in Saudi Arabia for funding this research work through the project number IFKSURP-113 and the APC was funded also by the same project.

Acknowledgments: The authors extend their appreciation to the Deputyship for Research \& Innovation, "Ministry of Education" in Saudi Arabia for funding this research work through the project number IFKSURP-113. The authors thank the Deanship of Scientific Research and RSSU at King Saud University for their technical support.

Conflicts of Interest: The authors declare no conflict of interest. 


\section{References}

1. Jugulam, M. Biology, Physiology and Molecular Biology of Weeds; CRC Press: Boca Raton, FL, USA, 2017.

2. $\quad$ Rice, E. Allelopathy, 2nd ed.; Academic Press: New York, NY, USA, 1984.

3. Abd El-Gawad, A.M.; Elshamy, A.I.; El Gendy, A.E.-N.; Gaara, A.; Assaeed, A.M. Volatiles profiling, allelopathic activity, and antioxidant potentiality of Xanthium strumarium leaves essential oil from Egypt: Evidence from chemometrics analysis. Molecules 2019, 24, 584. [CrossRef] [PubMed]

4. Assaeed, A.; Elshamy, A.; El Gendy, A.E.-N.; Dar, B.; Al-Rowaily, S.; Abd El-Gawad, A. Sesquiterpenes-rich essential oil from above ground parts of Pulicaria somalensis exhibited antioxidant activity and allelopathic effect on weeds. Agronomy 2020, 10, 399. [CrossRef]

5. Sharifi-Rad, J.; Sureda, A.; Tenore, G.C.; Daglia, M.; Sharifi-Rad, M.; Valussi, M.; Tundis, R.; Sharifi-Rad, M.; Loizzo, M.R.; Ademiluyi, A.O. Biological activities of essential oils: From plant chemoecology to traditional healing systems. Molecules 2017, 22, 70. [CrossRef]

6. Abd El-Gawad, A.M.; Elshamy, A.; El Gendy, A.E.-N.; Al-Rowaily, S.L.; Assaeed, A.M. Preponderance of oxygenated sesquiterpenes and diterpenes in the volatile oil constituents of Lactuca serriola L. revealed antioxidant and allelopathic activity. Chem. Biodivers. 2019, 16, e1900278. [CrossRef] [PubMed]

7. Elshamy, A.; Abd El-Gawad, A.M.; El-Amier, Y.A.; El Gendy, A.; Al-Rowaily, S. Interspecific variation, antioxidant and allelopathic activity of the essential oil from three Launaea species growing naturally in heterogeneous habitats in Egypt. Flavour Fragr. J. 2019, 34, 316-328. [CrossRef]

8. Abd El-Gawad, A.M.; El-Amier, Y.A.; Bonanomi, G. Essential oil composition, antioxidant and allelopathic activities of Cleome droserifolia (Forssk.) Delile. Chem. Biodivers. 2018, 15, e1800392. [CrossRef]

9. Abd El-Gawad, A.M.; El-Amier, Y.A.; Bonanomi, G. Allelopathic activity and chemical composition of Rhynchosia minima (L.) DC. essential oil from Egypt. Chem. Biodivers. 2018, 15, e1700438. [CrossRef]

10. Deng, W.; Liu, K.; Cao, S.; Sun, J.; Zhong, B.; Chun, J. Chemical composition, antimicrobial, antioxidant, and antiproliferative properties of grapefruit essential oil prepared by molecular distillation. Molecules 2020, 25, 217. [CrossRef]

11. Elshamy, A.I.; Ammar, N.M.; Hassan, H.A.; Al-Rowaily, S.L.; Raga, T.R.; El Gendy, A.; Abd El-Gawad, A.M. Essential oil and its nanoemulsion of Araucaria heterophylla resin: Chemical characterization, anti-inflammatory, and antipyretic activities. Ind. Crop. Prod. 2020, 148, 112272. [CrossRef]

12. Arunachalam, K.; Balogun, S.O.; Pavan, E.; de Almeida, G.V.B.; de Oliveira, R.G.; Wagner, T.; Cechinel Filho, V.; de Oliveira Martins, D.T. Chemical characterization, toxicology and mechanism of gastric antiulcer action of essential oil from Gallesia integrifolia (Spreng.) Harms in the in vitro and in vivo experimental models. Biomed. Pharmacother. 2017, 94, 292-306. [CrossRef]

13. Damtie, D.; Braunberger, C.; Conrad, J.; Mekonnen, Y.; Beifuss, U. Composition and hepatoprotective activity of essential oils from Ethiopian thyme species (Thymus serrulatus and Thymus schimperi). J. Essent. Oil Res. 2019, 31, 120-128. [CrossRef]

14. Zhang, J.; An, M.; Wu, H.; Li Liu, D.; Stanton, R. Chemical composition of essential oils of four Eucalyptus species and their phytotoxicity on silverleaf nightshade (Solanum elaeagnifolium Cav.) in Australia. Plant. Growth Regul. 2012, 68, 231-237. [CrossRef]

15. Abd El-Gawad, A.M.; Elshamy, A.; El-Amier, Y.A.; El Gendy, A.; Al-Barati, S.; Dar, B.; Al-Rowaily, S.; Assaeed, A. Chemical composition variations, allelopathic, and antioxidant activities of Symphyotrichum squamatum (Spreng.) Nesom essential oils growing in heterogeneous habitats. Arab. J. Chem. 2020, 13, 237-4245. [CrossRef]

16. Bozok, F.; Ulukanli, Z. Volatiles from the aerial parts of east Mediterranean clary sage: Phytotoxic activity. J. Essent. Oil Bear. Plants 2016, 19, 1192-1198. [CrossRef]

17. Pinheiro, P.F.; Costa, A.V.; Tomaz, M.A.; Rodrigues, W.N.; Fialho Silva, W.P.; Moreira Valente, V.M. Characterization of the Essential Oil of Mastic Tree from Different Biomes and its Phytotoxic Potential on Cobbler's Pegs. J. Essent. Oil Bear. Plants 2016, 19, 972-979. [CrossRef]

18. Agnieszka, S.; Magdalena, R.; Jan, B.; Katarzyna, W.; Malgorzata, B.; Krzysztof, H.; Danuta, K. Phytotoxic effect of fiber hemp essential oil on germination of some weeds and crops. J. Essent. Oil Bear. Plants 2016, 19, 262-276. [CrossRef]

19. Bali, A.S.; Batish, D.R.; Singh, H.P.; Kaur, S.; Kohli, R.K. Chemical characterization and phytotoxicity of foliar volatiles and essential oil of Callistemon viminalis. J. Essent. Oil Bear. Plants 2017, 20, 535-545. [CrossRef]

20. Fouad, R.; Bousta, D.; Lalami, A.E.O.; Chahdi, F.O.; Amri, I.; Jamoussi, B.; Greche, H. Chemical composition and herbicidal effects of essential oils of Cymbopogon citratus (DC) Stapf, Eucalyptus cladocalyx, Origanum vulgare L and Artemisia absinthium L. cultivated in Morocco. J. Essent. Oil Bear. Plants 2015, 18, 112-123. [CrossRef]

21. Poonpaiboonpipat, T.; Pangnakorn, U.; Suvunnamek, U.; Teerarak, M.; Charoenying, P.; Laosinwattana, C. Phytotoxic effects of essential oil from Cymbopogon citratus and its physiological mechanisms on barnyardgrass (Echinochloa crus-galli). Ind. Crop. Prod. 2013, 41, 403-407. [CrossRef]

22. Kordali, S.; Cakir, A.; Ozer, H.; Cakmakci, R.; Kesdek, M.; Mete, E. Antifungal, phytotoxic and insecticidal properties of essential oil isolated from Turkish Origanum acutidens and its three components, carvacrol, thymol and p-cymene. Bioresour. Technol. 2008, 99, 8788-8795. [CrossRef]

23. Verdeguer, M.; Blázquez, M.A.; Boira, H. Phytotoxic effects of Lantana camara, Eucalyptus camaldulensis and Eriocephalus africanus essential oils in weeds of Mediterranean summer crops. Biochem. Syst. Ecol. 2009, 37, 362-369. [CrossRef] 
24. Ulukanli, Z.; Çenet, M.; Öztürk, B.; Bozok, F.; Karabörklü, S.; Demirci, S.C. Chemical characterization, phytotoxic, antimicrobial and insecticidal activities of Vitex agnus-castus' essential oil from East Mediterranean Region. J. Essent. Oil Bear. Plants 2015, 18, 1500-1507. [CrossRef]

25. Kashkooli, A.B.; Saharkhiz, M.J. Essential oil compositions and natural herbicide activity of four Denaei Thyme (Thymus daenensis Celak.) ecotypes. J. Essent. Oil Bear. Plants 2014, 17, 859-874. [CrossRef]

26. Ulukanli, Z.; Cenet, M.; Ince, H.; Yilmaztekin, M. Antimicrobial and herbicidal activities of the essential oil from the Mediterranean Thymus eigii. J. Essent. Oil Bear. Plants 2018, 21, 214-222. [CrossRef]

27. Ulukanli, Z.; Bozok, F.; Cenet, M.; Ince, H.; Demirci, S.C.; Sezer, G. Secondary metabolites and bioactivities of Thymbra spicata var. spicata in Amanos mountains. J. Essent. Oil Bear. Plants 2016, 19, 1754-1761. [CrossRef]

28. Bozok, F. Herbicidal Activity of Nepeta flavida Essential Oil. J. Essent. Oil Bear. Plants 2018, 21, 1687-1693. [CrossRef]

29. Silva, E.R.; Overbeck, G.E.; Soares, G.L.G. Phytotoxicity of volatiles from fresh and dry leaves of two Asteraceae shrubs: Evaluation of seasonal effects. S. Afr. J. Bot. 2014, 93, 14-18. [CrossRef]

30. Da Silva, E.R.; Lazarotto, D.C.; Pawlowski, A.; Schwambach, J.; Soares, G.L.G. Antioxidant Evaluation of Baccharis patens and Baccharis psiadioides Essential Oils. J. Essent. Oil Bear. Plants 2018, 21, 485-492. [CrossRef]

31. Mancini, E.; Arnold, N.A.; De Martino, L.; De Feo, V.; Formisano, C.; Rigano, D.; Senatore, F. Chemical composition and phytotoxic effects of essential oils of Salvia hierosolymitana Boiss. and Salvia multicaulis Vahl. var. simplicifolia Boiss. growing wild in Lebanon. Molecules 2009, 14, 4725-4736. [CrossRef]

32. Kaur, S.; Singh, H.P.; Mittal, S.; Batish, D.R.; Kohli, R.K. Phytotoxic effects of volatile oil from Artemisia scoparia against weeds and its possible use as a bioherbicide. Ind. Crop. Prod. 2010, 32, 54-61. [CrossRef]

33. Aragão, F.; Palmieri, M.; Ferreira, A.; Costa, A.; Queiroz, V.; Pinheiro, P.; Andrade-Vieira, L. Phytotoxic and cytotoxic effects of Eucalyptus essential oil on lettuce (Lactuca sativa L.). Allelopath. J. 2015, 35, 259-272.

34. Pinheiro, P.F.; Costa, A.V.; Alves, T.d.A.; Galter, I.N.; Pinheiro, C.A.; Pereira, A.F.; Oliveira, C.M.R.; Fontes, M.M.P. Phytotoxicity and cytotoxicity of essential oil from leaves of Plectranthus amboinicus, carvacrol, and thymol in plant bioassays. J. Agric. Food Chem. 2015, 63, 8981-8990. [CrossRef]

35. Ulukanli, Z.; Karabörklü, S.; Bozok, F.; Burhan, A.; Erdogan, S.; Cenet, M.; KARAASLAN, M.G. Chemical composition, antimicrobial, insecticidal, phytotoxic and antioxidant activities of Mediterranean Pinus brutia and Pinus pinea resin essential oils. Chin. J. Nat. Med. 2014, 12, 901-910. [CrossRef]

36. Amri, I.; Gargouri, S.; Hamrouni, L.; Hanana, M.; Fezzani, T.; Jamoussi, B. Chemical composition, phytotoxic and antifungal activities of Pinus pinea essential oil. J. Pest. Sci. 2012, 85, 199-207. [CrossRef]

37. Ulukanli, Z.; Karabörklü, S.; Bozok, F.; Çenet, M.; Öztürk, B.; Balcilar, M. Antimicrobial, insecticidal and phytotoxic activities of Cotinus coggyria Scop. essential oil (Anacardiaceae). Nat. Prod. Res. 2014, 28, 2150-2157. [CrossRef]

38. Saharkhiz, M.J.; Smaeili, S.; Merikhi, M. Essential oil analysis and phytotoxic activity of two ecotypes of Zataria multiflora Boiss. growing in Iran. Nat. Prod. Res. 2010, 24, 1598-1609. [CrossRef]

39. Mahdavikia, F.; Saharkhiz, M.J. Phytotoxic activity of essential oil and water extract of peppermint (Mentha $\times$ piperita L. CV. Mitcham). J. Appl. Res. Med. Aromat. Plants 2015, 2, 146-153. [CrossRef]

40. De Almeida, L.F.R.; Frei, F.; Mancini, E.; De Martino, L.; De Feo, V. Phytotoxic activities of Mediterranean essential oils. Molecules 2010, 15, 4309-4323. [CrossRef]

41. Zahed, N.; Hosni, K.; Ben Brahim, N.; Kallel, M.; Sebei, H. Allelopathic effect of Schinus molle essential oils on wheat germination. Acta Physiol. Plant. 2010, 32, 1221-1227. [CrossRef]

42. De Oliveira, M.S.; da Costa, W.A.; Pereira, D.S.; Botelho, J.R.S.; de Alencar Menezes, T.O.; de Aguiar Andrade, E.H.; da Silva, S.H.M.; da Silva Sousa Filho, A.P.; de Carvalho Junior, R.N. Chemical composition and phytotoxic activity of clove (Syzygium aromaticum) essential oil obtained with supercritical $\mathrm{CO}_{2}$. J. Supercrit. Fluid. 2016, 118, 185-193. [CrossRef]

43. Verdeguer, M.; García-Rellán, D.; Boira, H.; Pérez, E.; Gandolfo, S.; Blázquez, M.A. Herbicidal activity of Peumus boldus and Drimys winterii essential oils from Chile. Molecules 2011, 16, 403-411. [CrossRef] [PubMed]

44. Kim, J. Phytotoxic and antimicrobial activities and chemical analysis of leaf essential oil from Agastache rugosa. J. Plant. Biol. 2008, 51, 276-283. [CrossRef]

45. Grichi, A.; Nasr, Z.; Khouja, M.L. Phytotoxic effects of essential oil from Eucalyptus lehmanii against weeds and its possible use as a bioherbicide. Bull. Environ. Pharmacol. Life Sci. 2016, 5, 17-23.

46. Salamci, E.; Kordali, S.; Kotan, R.; Cakir, A.; Kaya, Y. Chemical compositions, antimicrobial and herbicidal effects of essential oils isolated from Turkish Tanacetum aucheranum and Tanacetum chiliophyllum var. chiliophyllum. Biochem. Syst. Ecol. 2007, 35, 569-581. [CrossRef]

47. Singh, R.; Ahluwalia, V.; Singh, P.; Kumar, N.; Prakash Sati, O.; Sati, N. Antifungal and phytotoxic activity of essential oil from root of Senecio amplexicaulis Kunth.(Asteraceae) growing wild in high altitude-Himalayan region. Nat. Prod. Res. 2016, 30, 1875-1879. [CrossRef] [PubMed]

48. Ahluwalia, V.; Sisodia, R.; Walia, S.; Sati, O.P.; Kumar, J.; Kundu, A. Chemical analysis of essential oils of Eupatorium adenophorum and their antimicrobial, antioxidant and phytotoxic properties. J. Pest. Sci. 2014, 87, 341-349. [CrossRef]

49. Pawlowski, Â.; Kaltchuk-Santos, E.; Brasil, M.; Caramão, E.; Zini, C.; Soares, G. Chemical composition of Schinus lentiscifolius March. essential oil and its phytotoxic and cytotoxic effects on lettuce and onion. S. Afr. J. Bot. 2013, 88, 198-203. [CrossRef] 
50. Abd El-Gawad, A.M. Chemical constituents, antioxidant and potential allelopathic effect of the essential oil from the aerial parts of Cullen plicata. Ind. Crops Prod. 2016, 80, 36-41. [CrossRef]

51. Zhu, X.; Han, C.; Gao, T.; Shao, H. Chemical composition, phytotoxic and antimicrobial activities of the essential oil of Scutellaria strigillosa Hemsley. J. Essent. Oil Bear. Plants 2016, 19, 664-670. [CrossRef]

52. Razavi, S.M.; Narouei, M.; Majrohi, A.A.; Chamanabad, H.R.M. Chemical constituents and phytotoxic activity of the essential oil of Acroptilon repens (L.) Dc from Iran. J. Essent. Oil Bear. Plants 2012, 15, 943-948. [CrossRef]

53. El Ayeb-Zakhama, A.; Ben Salem, S.; Sakka-Rouis, L.; Flamini, G.; Ben Jannet, H.; Harzallah-Skhiri, F. Chemical composition and phytotoxic effects of essential oils obtained from Ailanthus altissima (Mill.) swingle cultivated in Tunisia. Chem. Biodivers. 2014, 11, 1216-1227. [CrossRef] [PubMed]

54. Abd El-Gawad, A.; El Gendy, A.; El-Amier, Y.; Gaara, A.; Omer, S.; Al-Rowaily, S.; Assaeed, A.; Al-Rashed, S.; Elshamy, A. Essential oil of Bassia muricata: Chemical characterization, antioxidant activity, and allelopathic effect on the weed Chenopodium murale. Saudi J. Biol. Sci. 2020, 27, 1900-1906. [CrossRef] [PubMed]

55. Martino, L.D.; Formisano, C.; Mancini, E.; Feo, V.D.; Piozzi, F.; Rigano, D.; Senatore, F. Chemical composition and phytotoxic effects of essential oils from four Teucrium species. Nat. Prod. Commun. 2010, 5, 1969-1976. [CrossRef] [PubMed]

56. Razavi, S.M.; Nejad-Ebrahimi, S. Phytochemical analysis and allelopathic activity of essential oils of Ecballium elaterium A. Richard growing in Iran. Nat. Prod. Res. 2010, 24, 1704-1709. [CrossRef] [PubMed]

57. Mutlu, S.; Atici, Ö.; Esim, N.; Mete, E. Essential oils of catmint (Nepeta meyeri Benth.) induce oxidative stress in early seedlings of various weed species. Acta Physiol. Plant. 2011, 33, 943-951. [CrossRef]

58. Kordali, S.; Tazegul, A.; Cakir, A. Phytotoxic effects of Nepeta meyeri Benth. extracts and essential oil on seed germinations and seedling growths of four weed species. Rec. Nat. Prod. 2015, 9, 404-418.

59. Saharkhiz, M.J.; Zadnour, P.; Kakouei, F. Essential oil analysis and phytotoxic activity of catnip (Nepeta cataria L.). Am. J. Essent. Oils Nat. Prod. 2016, 4, 40-45.

60. Bozok, F.; Cenet, M.; Sezer, G.; Ulukanli, Z. Essential oil and bioherbicidal potential of the aerial parts of Nepeta nuda subsp. albiflora (Lamiaceae). J. Essent. Oil Bear. Plants 2017, 20, 148-154. [CrossRef] 